Studia i materiały $\mathrm{z}$ dziedzictwa kulturowego Torunia i regionu, t. 1: STARE I NOWE DZIEDZICTWO TORUNIA,

Toruń 2013

http://dx.doi.org/10.12775/SiMzDzKTiR_T1.2013.002

Kazimierz Pospieszny

(MALBORK)

\title{
Kościół zamkowy w Toruniu- próba rekonstrukcji formy budowlanej i programu ikonograficznego
}

Nieustanna segregacja materiału z badań archeologicznych krzyżackiego zamku konwentualnego w Toruniu $z$ lat 1958-1966, studia artefaktów typowanych do ekspozycji muzealnych, a także prace konserwatorskie na murach i przy detalach wystroju sprawiają, że obraz architektoniczny budowli wyburzonej po 1454 roku (z wyjątkiem gdaniska) z roku na rok przedstawia się coraz bardziej klarownie ${ }^{1}$. Przede wszystkim przewaga znalezisk kompletnych detali wskazuje, że po zniesieniu władzy Zakonu intencją miasta nie było obrócenie zamku w perzynę. Imponująca liczba „nieużytecznych” elementów wystroju, jak kapitele i bazy, trzony, cokoły, profilowane ościeża, maswerki okienne, zworniki itp., przekonuje o pragmatycznej postawie rady Starego Miasta w okresie wielkich zmian ${ }^{2}$. Wprawdzie wysadzono w powietrze wieżę główną, symbol władzy Zakonu, jednak budynki mieszkalne konwentu konsekwentnie rozbierano, wykorzystując pozyskany tą drogą materiał budowlany do nowych celów. Liczne, pozostawione na miejscu elementy i detale, ważne niegdyś dla Zakonu, a nie znajdujące zastosowania w nowych czasach ocalały, ukryte pod warstwą gruzu, z czasem pod „górą" składowanych tam śmieci. Ten jedyny w swoim rodzaju, niezwykle wartościowy zbiór detali architektonicznych, pozyskany w ostatnich czasach z jednej budowli, złożył się na sukces badań archeologicznych zamku.

W odczytanym na nowo planie zabudowy założenia zamkowego cechy formalne detalu budowlanego (mapowanego) pozwoliły na identyfikację pomieszczeń wspólnotowych domu konwentu, takich jak kaplica, kapitularz, refektarz oraz krużganek (il. 1) ${ }^{3}$. W wielkim zespole materiałów zwracała uwagę plastyka architektoniczna z kościoła zamkowego

1 Zbigniew NAWROCKI, Zamek krzyżacki w Toruniu. Dzieje budowy, upadek, ponowne zagospodarowanie, „Rocznik Muzeum Okręgowego w Toruniu”, t. 13/14 , 2005, s. 25-26.

2 Janusz TANDECKI, Toruń historia i rozwój przestrzenny, [w:] Atlas historyczny miast polskich, t. I, z. 2 Toruń, oprac. J. TANDECKI, Z. KOZIOE, Toruń 1995, s. 7.

3 Jerzy FRYCZ, Zamek krzyżacki w Toruniu, „Rocznik Muzeum Okręgowego w Toruniu”, t. 3, 1963; Roman DOMAGAŁA, Detale architektoniczne z zamku krzyżackiego w Toruniu, [w:] Komunikaty na sesje naukowa poświęcona dziełom sztuki Pomorza zorganizowana w 500-lecie Pokoju Toruńskiego, Toruń 5-7 września 1966, s. 13-21. 
pw. św. Krzyża ${ }^{4}$ Poza odsłoniętymi in situ fragmentami dolnych partii murów głównego piętra, stano-wiła ona nieznany wcześniej materiał ikonograficzny do badań architektury świątyni konwentualnej. Mimo swej niezbywalnej wartości źródłowej materiał ten był w niewielkim stopniu wykorzystywany w kolejnych latach badań. Pomijając portal, prowadzący do kościoła z krużganka, uznawany za pierwotny, najważniejsze z detali, które pochodziły ze sklepienia, luźno kojarzono z najstarszymi wzmiankami archiwalnymi. Jedne z pierwszych przekazów pisanych dotyczyły kościoła. W liście intencyjnym legata papieskiego Anzelma z 1263 roku napisano, że „fratrem capellam in castro de novo construere proponunt opere sumptuoso". Wzmiankę o rozpoczętej nowej budowie kaplicy zamkowej kojarzono raczej z głównym etapem realizacji murowanego skrzydła południowego aniżeli z przebudową konstrukcji murów kościoła, w istocie wzniesionych dużo wcześniej. Przy tym partie murów „jednonawowego” kościoła, a także pomieszczenia usytuowanego pod nim, na tym samym rzucie w parterze, nie wykazywały więcej jak jedną zmianę budowlaną. Modyfikację tą łączono z przesklepieniem pomieszczeń w latach ok. 1270-1280, zatem późniejszym o jedną albo i dwie dekady niż wzmianka źródłowa (il. 2). Jeżeli przyjąć, że gniazda belek stropowych parteru (bardzo dobrze zachowane w warstwie podsypki pod posadzką) wykonano w latach 60 . XIII wieku, to ich natychmiastowa przebudowa wydawała się mało prawdopodobna. Szybka zamiana drewnianych stropów na murowane konstrukcje sklepienne stanowiła precedens w praktyce inwestorskiej. Wyjątki w tej kwestii należało traktować jako przypadki wymuszone przez bieżące okoliczności. Zmiany konstrukcyjne bywały następstwem burzliwych wydarzeń, np. zbrojnych napadów Prusów, które niosły katastrofalne skutki dla budowli drewnianych ${ }^{5}$. Takie okoliczności w Toruniu jednak nie wystąpiły. W tym przypadku opowiadano się zwykle za przerwą w budowie zamku, inwestycją nominalnie rozpoczętą po translokacji Torunia w 1236 roku. Rozpoczęcie lub wznowienie prac po długotrwałym przestoju, poświadczone wzmianką z 1255 roku, można było złożyć na karb głębokiego kryzysu władzy Zakonu, wywołanego pierwszym powstaniem pruskim.

Konkretne dane odnośnie do architektury zamkowej pochodziły z późniejszych źródeł archiwalnych i dotyczyły świątyni dwunawowej. Wzmianki te, mimo iż jednoznaczne w swej wymowie, bardziej komplikowały, niż rozjaśniały obraz. Odnosiły się one do konstrukcji halowej, powiązanej - jak należało sądzić - ze sklepieniami typu, który (znany z kapitularzy) jako taki nie występował w krzyżackich kościołach zamkowych. Brakowało materiału porównawczego. W tej nie rokującej na przyszłość sytuacji znaleziska kluczowych detali sklepiennych, zlokalizowane precyzyjne w obrębie miejsca budowli dawały niepowtarzalną szansę rozwoju badań.

W skład zespołu detali z plastyką o motywach figuralnych i florystycznych wchodził, oprócz elementów portalu, także zespół detali sklepiennych, ze względu na materiał oraz

4 Świątynie konwentualne wydzielone prawem egzempcji ze struktury diecezjalnej oferowały pełny zakres kościelnych posług parafialnych: Waldemar ROZYNKOWSKI, Omnes Sancti et Sanctae Dei. Studium nad kultem świętych w diecezjach pruskich państwa zakonu krzyżackiego, Malbork 2006.

5 Marian ARSZYŃSKI, Budownictwo warowne zakonu krzyżackiego Prusach (1230-1454). Toruń1995, s. 115-151. 
skalę obiektów łatwo podzielny na dwie grupy. W zespole służek, kapiteli i zworników sklepiennych w znacznej liczbie wystąpiły te w materiale ceramicznym, o niewielkiej, niemalże „karłowatej” skali (il. 3). Różniły się one od pojedynczych detali w sztucznym kamieniu, dwu-, dwuipółkrotnie większych i żywo polichromowanych. Wśród tych ostatnich dominował destrukt zwornika talerzowego (średnica $58 \mathrm{~cm}$ ) ze sceną figuralną, interpretowaną w literaturze jako przedstawienie Ucieczki do Egiptu $u^{6}$ Wyróżniał się on w grupie zworników konstrukcyjnych z gliny palonej, o niewielkiej średnicy $(22 \mathrm{~cm})$, zachowanych w liczbie sześciu, również opatrzonych motywami obrazowymi o wymowie symbolicznej. To ów ocalały symbol ewangelisty św. Jana (orzeł z nimbem i banderolą) i jednocześnie brak zworników ze znakami pozostałych trzech ewangelistów, zwiększał pierwotną liczba zworników tego typu do dziewięciu. Tym samym charakterystyka detalu wskazywała na dwoistą strukturę sklepienia kościoła. Małe zworniki konstrukcyjne przekonywały, iż faktycznie składało się ono z czterech par niewielkich przęseł krzyżowo-żebrowych, w układzie dwunawowym, i jednego równie małego, osobnego przęsła. Tą strukturę w obrębie prostokątnego, wydłużonego wnętrza uzupełniało jedno „wielkie” przęsło. Bez wątpienia chodziło tu o halę po stronie zachodniej, dwunawową względem osi wzdłużnej, oraz jedno wielkie przęsło sklepienne od wschodu. Do tego dochodziła jednoprzęsłowa, mała wnęka ołtarzowa, którą sklepiono krzyżowo-żebrowo, podobnie jak przestrzeń naw po stronie zachodniej. Za takim rozwiązaniem przemawiał cały zespół danych geometrycznych zachowanego pomieszczenia, także tych „zakodowanych” w detalu. Geometria prostokątnych przęseł nawowych charakteryzowała się powtarzalnymi kątami $64^{\circ}$ i $116^{\circ}$ na przecięciu żeber , które wykazywał każdy ze zworników. Profile żeber zaznaczone na trzonach klińców były proste, wklęskowe.

Do zespołu detali przęseł sklepiennych dochodziły kompozycje wiązkowych, trójwałkowych służek wraz z kapitelami kielichowymi o finezyjnej, jednostrefowej dekoracji - wszystkie detale w jednakowej „miniaturowej” skali. Zapewne służki te - jak sugerował element z potrójnymi, rogowymi wspornikami - były nadwieszone na sposób cysterski. Zwracało uwagę mistrzostwo warsztatowe na obu płaszczyznach: techniczne, w kształtowaniu plastyki z gotyckim, naturalistycznym ornamentem roślinnym (wić winorośli, bylica pospolita, pęd dębu) oraz technologii gliny palonej. Charakterystyczne motywy figuralne, jak scena walki dwunożnych smoków, przerobione na miękkie, niemalże wegetalne kształty z archaicznej stylistyki taśmowo-okuciowej, spotykanej w drugiej ćwierci XIII wieku (il. 4 a), kazały widzieć w tym dziele tradycję warsztatów brandenburskich (il. 4 b) $)^{7}$. Post-klasyczna rzeźba architektoniczna $\mathrm{w}$ redakcji brandenburskiej została zastosowana $\mathrm{w}$ kolejnych kościołach zamków konwentualnych na północy państwa krzyżackiego (w delcie Wisły i nad Zalewem Wiślanym), w Brandenburgu po 1266 roku, Malborku w latach 80. XIII wieku i Lochstedt po 1296 r. (il. 5 a-b).

Przestrzeń liturgiczną toruńskiego kościoła zamkowego zaaranżowano dwubiegunowo

6 Według archeologicznej siatki arów znaleziony na granicy terenu kościoła i refektarza, DOMAGAŁA 1966, s. 14; Tomasz TORBUS, Die Konventsburgen im Deutschordensland Preussen, München 1998, s. 684.

7 Krużganek katedralny w Brandenburgu: Dirk SCHUMANN, Die Berliner Franziskanerklosterkirche und Ihr Dekor, Berlin 2003, s. 114-115; motyw walki potworów w sztuce ludów barbarzyńskich, George HENDERSON, Wczesne średniowiecze, Warszawa 1987, s. 71-98. 
dzięki zróżnicowaniu formy i skali sklepień (il. 6). Jeżeli dwie trzecie powierzchni od strony zachodniej zajęła podłużna, dwunawowa hala z rzędem czterech filarów na osi (I-IV), to część prezbiterialną, poprzecznie prostokątną, nakryto na całej szerokości jednym przęsłem. Do tego na jego przedłużeniu, na osi wzdłużnej dołączono wnękę ołtarzową. Tym samym oś kościoła na kierunku wschód-zachód została zaznaczona przez rząd filarów, rozdzielających nawy, oraz wytyczona przez zworniki przęseł prezbiterialno-ołtarzowych.

Nie tylko geometria rzutu, ale również proporcje wnętrza wykazywały dwoiste zróżnicowanie. W hali, ze względu na małą powierzchnię jednego przęsła (ok. 2,3 x 3,75 m) stosunek szerokości do wysokości osiągał wartość od 1:1,5 do 1:2 (poprzecznie od 1:2,5 do nawet 1:3) i należał do wysokich, natomiast w przęśle prezbiterialnym (szer. 7,5 m) był niski. Zapewne nie osiągał on tam wartości 1:1 przy zakładanej tej samej wysokości wnętrza po obu stronach kościoła. Z tej racji grzbiety sklepienia krzyżowo-żebrowego szerokiego przęsła chórowego musiały być na tej samej wysokości, co wąskich przęseł hali. Bardzo wąskie były też odpowiednio ściany tarczowe po stronie południowej, które wychodziły na zewnątrz budowli, co przy grubości ściany osiągającej dwa metry ograniczało wielkość okien do niewielkich szczelin, przypominających strzelnice (podobne otwory znajdują się w zachowanej ścianie „dormitorium” zamku w Papowie Biskupim). Dopiero okno w przęśle chórowym mogło być szerokie, jednak przy proporcjach wnętrza zapewne zachowało ono wrzecionowy kształt, znany zarówno z kościoła konwentualnego w Papowie, jak i z pierwszego kościoła w Malborku. Podobnej wielkości okno musiało znajdować się także od wschodu, w ściance wnęki ołtarzowej, co zwiększało ilość światła w przestrzeni prezbiterium.

Przestrzeń kościoła zamkowego w Toruniu poddana została architektonicznej polaryzacji na osi wschód zachód w proporcjach $1 / 3$ do 2/3. Przy stanach osobowych konwentów zakonnych zawarowanych w regule (dwunastu rycerzy oraz sześciu kapłanów) ${ }^{8}$, prowadziło to do zrozumiałego wydzielenia dwóch kompartymentów: rycerskiego i kapłańskiego. Wnętrze kościoła toruńskiego w części halowej, rycerskiej musiało przedstawiać się jako rozczłonkowane i ciemne, oraz zwarte i umiarkowanie jasne w części chórowej, kapłańskiej. Taka struktura przestrzenna świątyni zakonnej nie była zjawiskiem odosobnionym w Prusach. Podobnie ukształtowany został pierwszy i drugi kościół zamkowy NMP w Malborku, z lat 80. XIII wieku i z lat 1331-1344 (il. 7). Tradycja kościołów bipolarnych z westwerkiem i chórem kapłańskim, miejscem dla władcy (na emporze zachodniej) i jego rycerzy (w hali przyziemia) była znana w krajach niemieckich od czasów karolińskich i benedyktyńskiej Centuli, utrzymując swoją wysoką rangę społeczną do końca średniowiecza9

W dobie krucjat pruskich nowi milites Christi włączeni zostali w apokaliptyczny plan rozprawy z szatanem na ziemi. Struktura i program ikonograficzny architektury kościoła wskazywały na cel walki z poganami, z natury obciążonymi grzechem niewiary, sprzysiężonymi z szatanem. Przestrzeń świątyni stanowiła odbicie wyznawanej ideologii. Programowo świat ziemski był atakowany przez siły ciemności, które opisywane stronami świata zawsze

\footnotetext{
8 Struktura personalna konwentów zakonnych, Klaus MILITZER, Von Akkon zur Marienburg. Verfassung, Verwaltung und Sozialstruktur des Deutschen Ordens 1190-1309, „Quellen und Studien zur Geschichte des Deutschen Ordens", t. 56, Marburg 1999, s. 53-78.
}

9 Heinrich KLOTZ, Geschichte der deutschen Kunst, Bd. 1, Mittelalter 600-1400, München 1998, s. 78-79. 
nadciągały w symbolicznej topografii świątyni z zachodu. Tam też dawali im odpór rycerze zakonni, walczący ramię w ramię z zsyłanymi z nieba zastępami archaniołów, lokowanymi po stronie zachodniej chori angelorum (il. 7). Wezwanie kościoła toruńskiego wskazywało na obecność tam relikwii św. Krzyża, głównej relikwii krucjatowej w Prusach ${ }^{10}$. Sukces krucjatowy oznaczał tryumf Chrystusa-światła, którego ponownego przyjścia oczekiwano od Wschodu, jako wypełnienie apokaliptycznej wizji końca dziejów. W Toruniu halę rycerską, odwołującą się do znanej braciom zakonnym z krajów ich pochodzenia symboliki westwerku, wykorzystano do przedstawienia misji krucjatowej w Prusach. Przekonywały o tym symbole ewangelistów na czterech zwornikach (il. 6, nr 3-4, 7-8), które wskazywały na odsłonę ewangelizacyjną tej misji.

Zwornik główny, znany dotąd jako Ucieczka do Egiptu, odpowiadał wprawdzie symbolice świątyni zamkowej (il. 8a), jednak nie całkiem zgadzał się z matrycą kompozycyjną przedstawienia. W tradycji ikonograficznej Zachodu apokryficzny temat Ucieczki do Egiptu rządził się ustalonymi od wieków schematami. Pierwsza scena przedstawiała Marię z Dzieciątkiem na ośle prowadzonym przez św. Józefa w kierunku z lewa na prawo, czyli ze wschodu na zachód. Kierunek odwrotny, czytelny na zworniku toruńskim, zarezerwowany był dla ostatniej sceny Powrotu z Egiptu, jak to widać na zworniku Wielkiego Refektarza na Zamku Średnim w Malborku, wykonanym krótko przed połową XIV wieku (il. 8b) ${ }^{11}$. Aktualna atrybucja toruńskiego zwornika wynikała bardziej z niemożności identyfikacji grupy figuralnej, niż z rozpoznania podłoża ideowego. Odpowiadała interpretacji kierunku jazdy, rozumianej jako podróż z zachodu na wschód, czyli z Egiptu do Palestyny. Symbolika tryumfalnego powrotu odpowiadała propagandzie pruskiej misji Zakonu ${ }^{12}$. Jednak dla identyfikacji sceny decydująca była postać przedstawiona z tyłu osła, stojąca w bezruchu, (il. 9 a), charakterystyczna nie dla całej grupy w podróży, ale dla grupy powitalnej w scenie Wjazdu Chrystusa do Jerozolimy. W tradycji zachodnioeuropejskiej kierunek jazdy Chrystusa w tej scenie tak samo był z lewa na prawo, kiedy na Bliskim Wschodzie, na wschód od Jerozolimy, mógł być przedstawiany odwrotnie (il. 9 b) ${ }^{13}$. Tryumf Chrystusa zapowiadał rozprawę z szatanem, finał zgodny z podnoszonym tu końcem dziejów z Apokalipsy św. Jana. Zatem temat na zworniku toruńskiego kościoła zamkowego nie mógł dziwić. Kierunek jazdy na toruńskim zworniku, ze względu na fragmentaryczny stan zachowania dzieła, nie musiał oznaczać niezwykłego tu zapożyczenia z ikonografii Wschodu, mógł być pozycjonowany odwrotnie, od strony ołtarza. Kierunek ten mógł wskazywać na wspomniany apokryficzny wątek Powrotu św. Rodziny z Egiptu i tryumf Chrystusa po obaleniu bożków egipskich. Ten sam temat został przedstawiony w malborskim Wielkim Refektarzu jako antycypacja zwy-

10 Relikwie poświadczone w 2. poł. XIII w., ROZYNKOWSKI 2006, s. 168.

11 Bogna JAKUBOWSKA, Malborska „Ucieczka do Egiptu”- motyw i funkcja [w:] Sztuka i historia, (Materiały sesji SHS), red. M. BIELSKA-ŁACH, Warszawa 1992, s. 181-195.

12 Marian KUTZNER, Propaganda władzy Zakonu Niemieckiego w sztuce na terenie państwa zakonnego w Prusach [w:] Fundacje artystyczne na terenie państwa zakonnego w Prusach (dalej cyt. FUNDACJE 2010), t. 2, Eseje, red. B. POSPIESZNA, Malbork 2010, s. 237-251.

13 Wjazd Chrystusa przedstawiany był od lewej do prawej, w skrótowej redakcji w towarzystwie dwóch, niekiedy jednej osoby witającej, a dołączany celnik Zacheusz występował zawsze na drzewie, J. ENGELMANN, Einzug Christi in Jerusalem [w:] Lexikon der christlichen Kunst, Bd. 3, Stuttgart-Weimar 1999, s. 1747. 
cięskiej walki Zakonu z poganami w Prusach ${ }^{14}$. Niezależnie od tematu toruńskiego zwornika, końcowym obrazem w apokaliptycznym programie obrazowym kościoła był Baranek Eucharystyczny, stąd - zgodnie ze schematem ikonograficznym w proponowanej rekonstrukcji sklepienia - zwornik z jego przedstawieniem (il. 9) został umieszczony w kluczu wnęki ołtarzowej (il. 10).

W próbie rekonstrukcji budowy kościoła, architektura sklepienia przedstawiała się jednorodnie. Jednak ze względu na materiał zwornika głównego oraz na styl zachowanej tam rzeźby figuralnej, jego powstanie należało przenieść na pierwsze dekady XIV wieku, do początku złotego okresu rozwoju rzeźby figuralnej w Prusach ${ }^{15}$. Zapewne powstał on w czasie przebudowy i rozbudowy założenia zamkowego o skrzydło kapitularza i wieżę gdaniska, datowanych wraz z nowym krużgankiem i gankiem na lata ok. 1310-134016. Przęsło chórowe kościoła mogło wówczas zostać przebudowane w stylu reprezentowanym przez prezbiterium kościoła św. Jakuba w Toruniu lub przez sklepione wnętrza zamku w Radzyniu Chełmińskim, kościół i kapitularz. Wówczas proste, krzyżowo-żebrowe sklepienie zostałoby zastąpione przęsłem gwiaździstym, opartym na wyjściowej w takich razach osnowie krzyża. W Toruniu mogła to być gwiazda w połowie, po stronie dwunawowej hali sześcioramienna, w połowie zaś czteroramienna (il. 6). Ten typ sklepienia umożliwiał kopulaste ukształtowanie środkowej partii przęsła chórowego, co z kolei stwarzało szansę powiększenia okna $\mathrm{w}$ ścianie tarczowej od południa ${ }^{17}$. Według tej zasady przebudowane zostało sklepienie kościoła zamkowego w Malborku. Umożliwiło to prześwietlenie jego chóru wielkimi, „katedralnymi" oknami.

Oprócz koniecznej rozbudowy, spowodowanej powszechnym w XIV w. w Prusach wzrostem liczebności konwentów, zamek w Toruniu - podobnie jak inne domy konwentualne w Prusach - również uległ w tym czasie przebudowie, która miała wymiar ideowy. Kościół zamkowy z około 1263 roku, jeden z pierwszych tego rodzaju w Prusach krzyżackich, został zmodernizowany od wschodu, zaopatrzony w nowy, triumfalny w wymowie zwornik główny. Kościół prezentował strukturę przestrzeni i program ikonograficzny, które w sposób oryginalny, korzystając z tradycji, wychodziły naprzeciw potrzebom konwentu w Prusach, propagując idee krucjatowe ${ }^{18}$. Sprawą wyjątkową w tym przypadku stała się możliwość in-

14 Kazimierz POSPIESZNY, Zwornik ze sceną „Powrotu św. Rodziny z Egiptu” $z$ Wielkiego Refektarza $w$ Malborku hasło [w:], FUNDACJE 2010, t. 1, Katalog, red. B. POSPIESZNA, Malbork 2010, s. 41-42, kat. I.2.16.

15 Plastyka architektoniczna: Tadeusz JURKOWLANIEC, Gotycka rzeźba architektoniczna w Prusach, Wrocław 1989, s. 53-94; statuaryczne kolegia apostolskie: Juliusz RACZKOWSKI, Treści ideowe średniowiecznych zespołów kolegium apostolskiego w Prusach Krzyżackich, [w:] Visibilia et Invisibilia w sztuce średniowiecza. Księga poświęcona pamięci profesor Kingi Szczepkowskiej-Naliwajek, red. A. BADACH, M. JANISZEWSKA, M. TARKOWSKA, Warszawa 2009, s. 141-157; Anna BŁAŻEJEWSKA, Rzeźba w państwie krzyżackim od jego początków do wojny trzynastoletniej [w:] FUNDACJE 2010, t. 2, Eseje, s. 166-177.

16 Jerzy FRYCZ, Architektura zamków krzyżackich, [w:] Sztuka pobrzeża Bałtyku. Materiały Sesji Stowarzyszenia Historyków Sztuki, Gdańsk, listopad 1976, red. H. FRUBA, Warszawa 1978, s. 28-48.

17 Pośrednio śladem po dużym oknie witrażowym kościoła mogą być liczne ułamki barwnego szkła znalezione w 2012 r. w wykopie archeologicznym, przy narożniku południowo-wschodnim zamku konwentualnego. Podobne znaleziska w wykopie archeologicznym wykonanym przez A. Pawłowskiego pod oknami Letniego Refektarza Pałacu Wielkiego Mistrza w Malborku.

18 Kazimierz POSPIESZNY, Castrum Thorun po 1300 roku a „klasyczny” model zamku komturskiego w Prusach, 
terpretacji programu ikonograficznego nieistniejącej świątyni, tym samym otwarcia, jak należy sądzić, problematyki badawczej zabytku z górą pięć i pół wieku po jego zburzeniu.

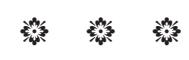

\section{Castle Church in Thorn/Torun-attempt to reconstruction of the building forms and iconographic program}

The essence of the study carried out on the material of the architectural and archaeological surveys of the ruins of the Conventual Teutonic castle in Torun in the years 1958-1966 was the combination of building artifacts collected of Holy Cross Church to the other types of sources, mainly written. Draft to build a new chapel from 1263, and data on a two-nave church vault helped accurately reproduce the structure in real space under the wing of the castle. On the basis of the iconography and the construction of small ceramic structural keystones (symbol St. John the Evangelist, mask, theme leaves the Eucharistic Lamb), to trace the closed vault spans nine cross-rib (rib fluted profile). Eight of them came in the hall for the Knights and one altar was closed cavity (Eucharistic Lamb). Big bay choir represented the combined form of four-and six-pointed star, similar to that of the St. James's church in Torun and the castle of the Teutonic Knights in Radzyń Chelminski, dating from 1309, and the second decade of the fourteenth century, the church presented twofold space bipolar type temple known for its capital castle in Malbork.

The iconography of the church referred to the Order crusades ideology of the dominant motive of Satan victorious struggle led by the hosts of heaven and earth militae Christi and the triumph of Christ. The main keystone of artificial stone in the eastern span of priests (reclaimed) presented the triumphal entry of Christ into Jerusalem. Perhaps it was also enriched by topic triumphant return of the Holy Family from Egypt (direction from right to left) after the overthrow of the Egyptian gods (apocryph), anticipating victory over the heathen crusades in Prussia.

[w:] Sztuka w kręgu władzy, red. E. PILECKA, K. KLUCZWAJD, Warszawa 2009, s. 75-88. 


\section{SPIS ILUSTRACJI:}

1. Toruń, ruina zamku konwentualnego w widoku z lotu ptaka: 1 - kościół; 2 - refektarz; 3 - kapitularz; 4 - krużganek, fot. A. Skowroński.

2. Toruń, zamek konwentualny, poziom parteru - stan zachowania murów pomieszczenia pod kościołem i kościoła zamkowego, fot. K. Pospieszny.

3. Toruń, detale architektoniczne z kościoła zamkowego, zbiory Muzeum Okręgowego w Toruniu: służka sklepienna z kapitelem, fragment archiwolty portalu, zworniki, fot. K. Pospieszny.

4. a) Brandenburg/Brandenburgia - kapitel służki sklepienia krużganka kapituły katedralnej; b) Toruń - kapitel służki sklepienia kościoła zamkowego, zbiory Muzeum Okręgowego w Toruniu, fot. K. Pospieszny.

5. a) Brandenburg Pr. - schemat konstrukcyjny sklepienia kościoła zamkowego, oprac. C. Steinbrecht 1888 r.; b) Malbork - schemat konstrukcyjny sklepienia pierwszego kościoła zamkowego, oprac. M. Kilarski 1993 r.

6. Schemat rzutu kościoła zamkowego w Toruniu wraz ze strukturą sklepień - próba rekonstrukcji, I-IV filary hali, 1-9 zworniki konstrukcyjne, ZG - zwornik główny. Kolor czarny - pierwsze sklepienie krzyżowo-żebrowe (liniami przerywanymi zaznaczono grzbiety wysklepek ostrołukowych), kolor czerwony - wariant z przęsłem gwiaździstym sklepienia chóru, oprac. K. Pospieszny.

7. Walka archaniołów z szatanem i nowych Machabeuszy z ludami Goga i Magoga - iluminacja z krzyżackiej Apokalipsy Heinricha Heslera (fragment), egz. ze Stuttgartu, repr. za kat. 800 Jahre Deutscher Orden, Gütersloh 1990.

8. a) Toruń, destrukt zwornika głównego z kościoła zamkowego, zbiory Muzeum Okręgowego w Toruniu, fot. A. Skowroński; b) Malbork - zwornik z Wielkiego Refektarza, fot. L. Okoński.

9. a) postać stojąca, fragment zwornika głównego, Toruń, kościół zamkowy, fot. autor; b) miniatura Wjazd Chrystusa do Jerozolimy, Mistrz Markare, Klasztor Hachpat (Armenia), 1211 r., rep. za Sztuka Świata, t. III.

10. Toruń, zwornik z przedstawieniem Baranka Eucharystycznego z kościoła zamkowego, zbiory Muzeum Okręgowego w Toruniu, fot. K. Pospieszny. 


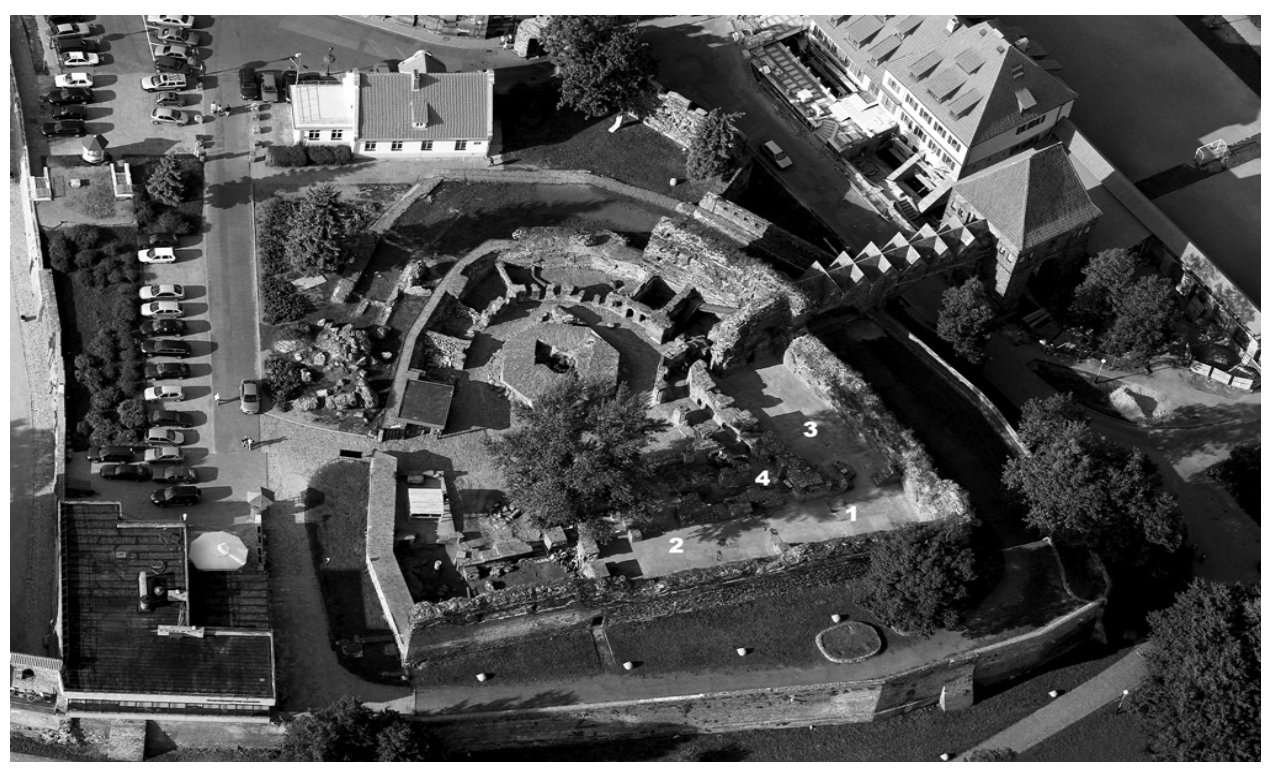

Il. 1 Toruń, ruina zamku konwentualnego w widoku z lotu ptaka: 1 - kościół; 2 - refektarz; 3 - kapitularz; 4 - krużganek, fot. A. Skowroński

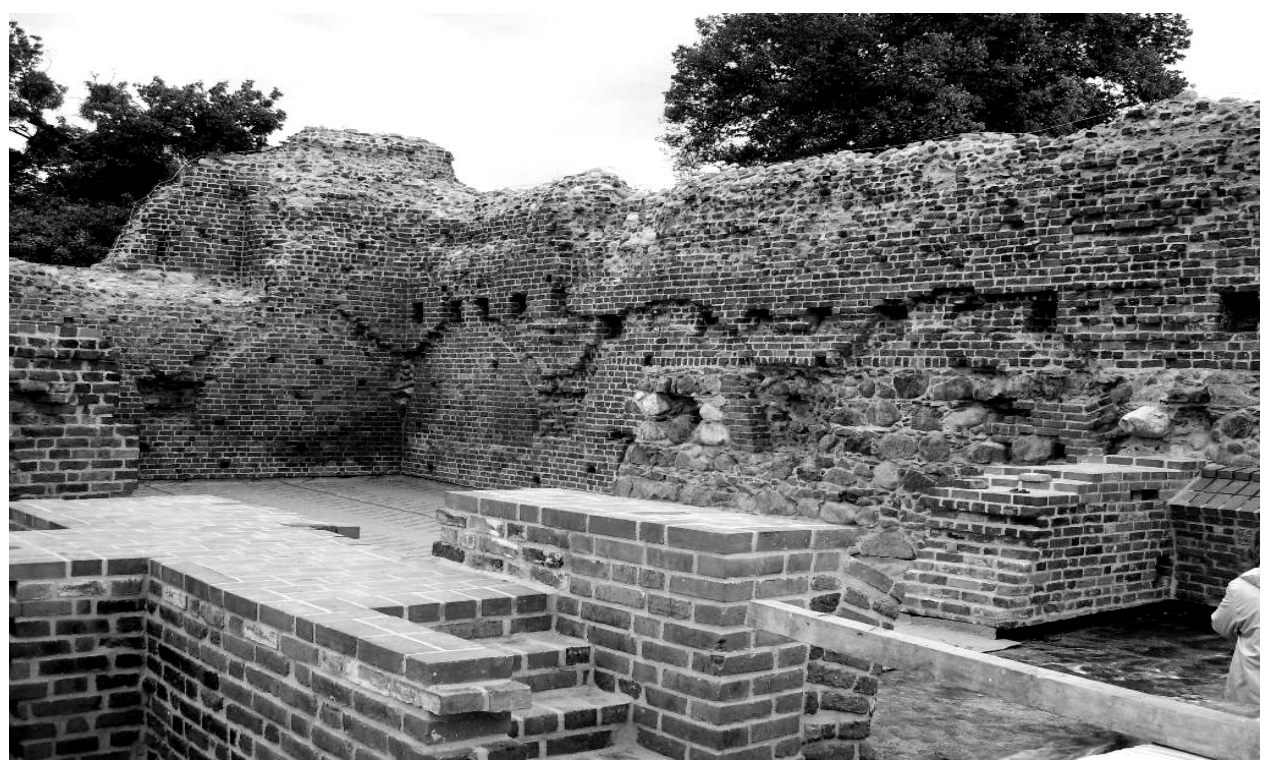

Il. 2 Toruń, zamek konwentualny, poziom parteru - stan zachowania murów pomieszczenia pod kościołem i kościoła zamkowego, fot. K. Pospieszny 


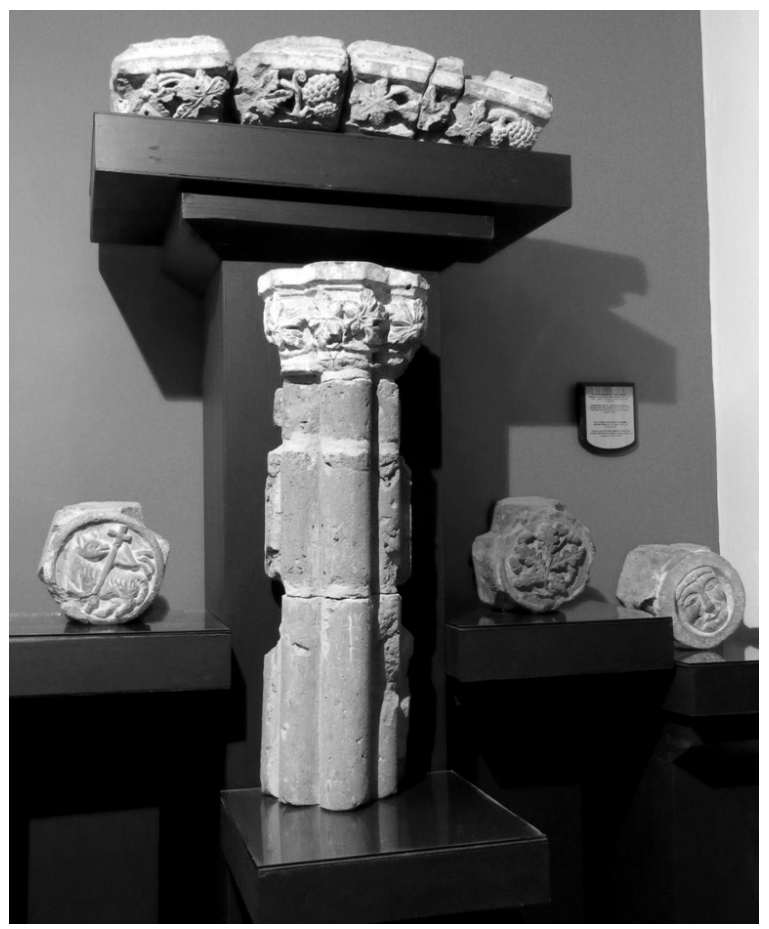

Il. 3 Toruń, detale architektoniczne z kościoła zamkowego, zbiory Muzeum Okręgowego w Toruniu: służka sklepienna z kapitelem, fragment archiwolty portalu, zworniki, fot. K. Pospieszny

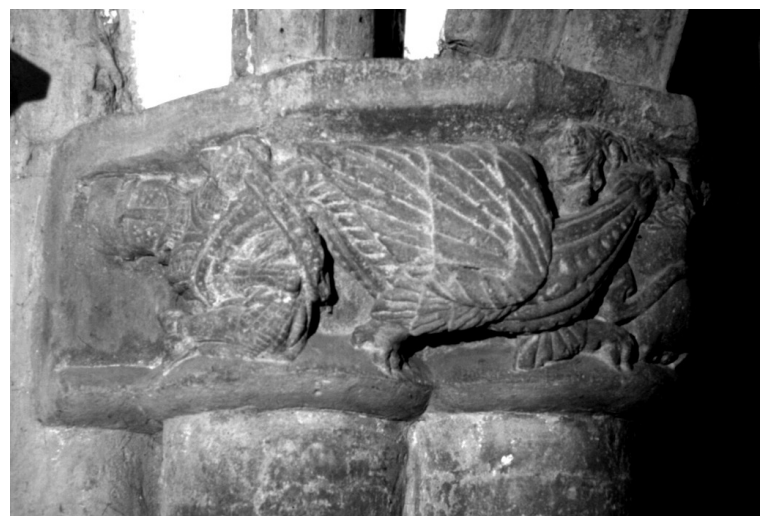

Il. 4a) Brandenburg/Brandenburgia - kapitel służkisklepienia krużganka kapituły katedralnej, fot. K. Pospieszny 


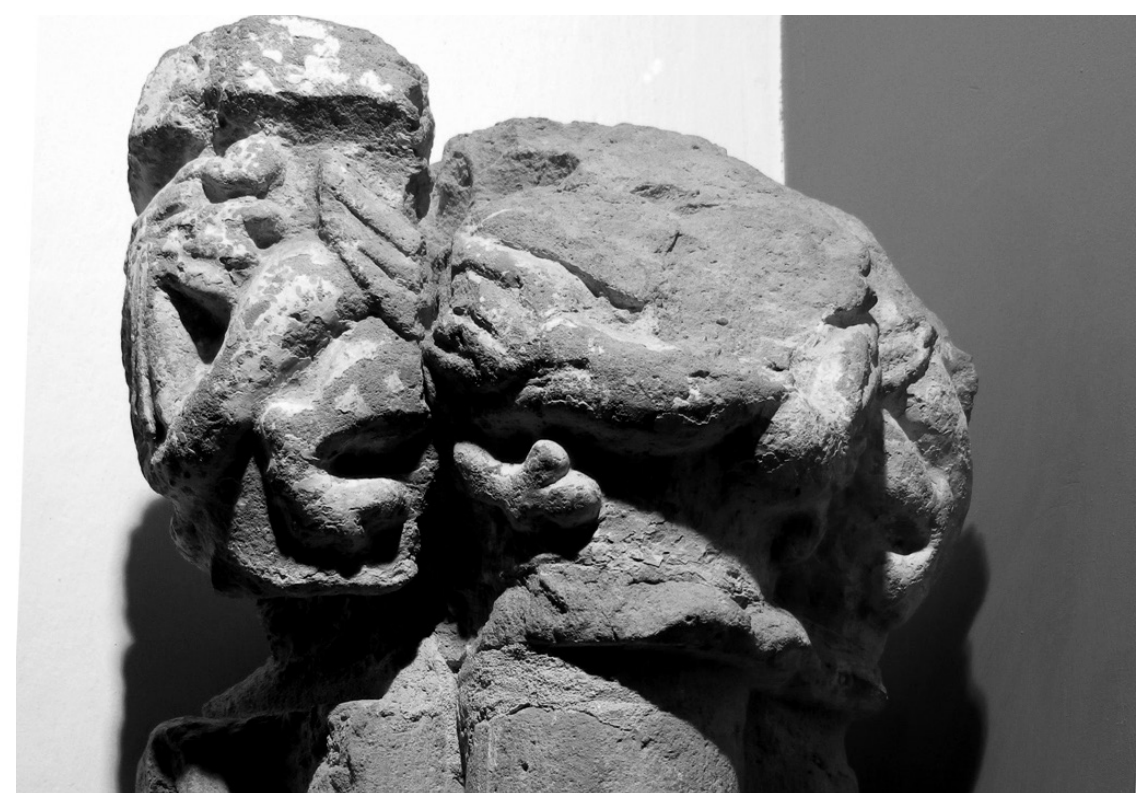

Il. 4b) Toruń - kapitel służki sklepienia kościoła zamkowego, zbiory Muzeum Okręgowego w Toruniu, fot. K. Pospieszny
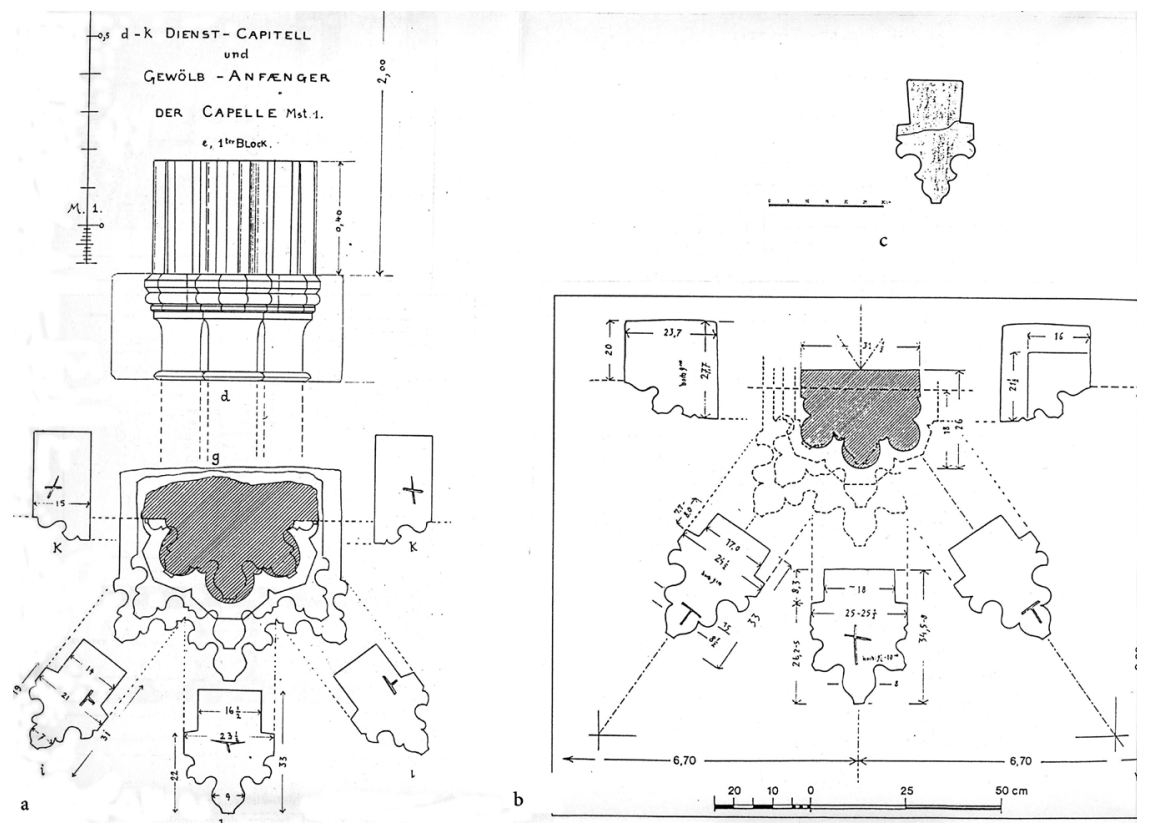

Il. 5a) Brandenburg Pr. - schemat konstrukcyjny sklepienia kościoła zamkowego, oprac. C. Steinbrecht 1888 r., b). Malbork - schemat konstrukcyjny sklepienia pierwszego kościoła zamkowego, oprac. M. Kilarski 1993 r. 


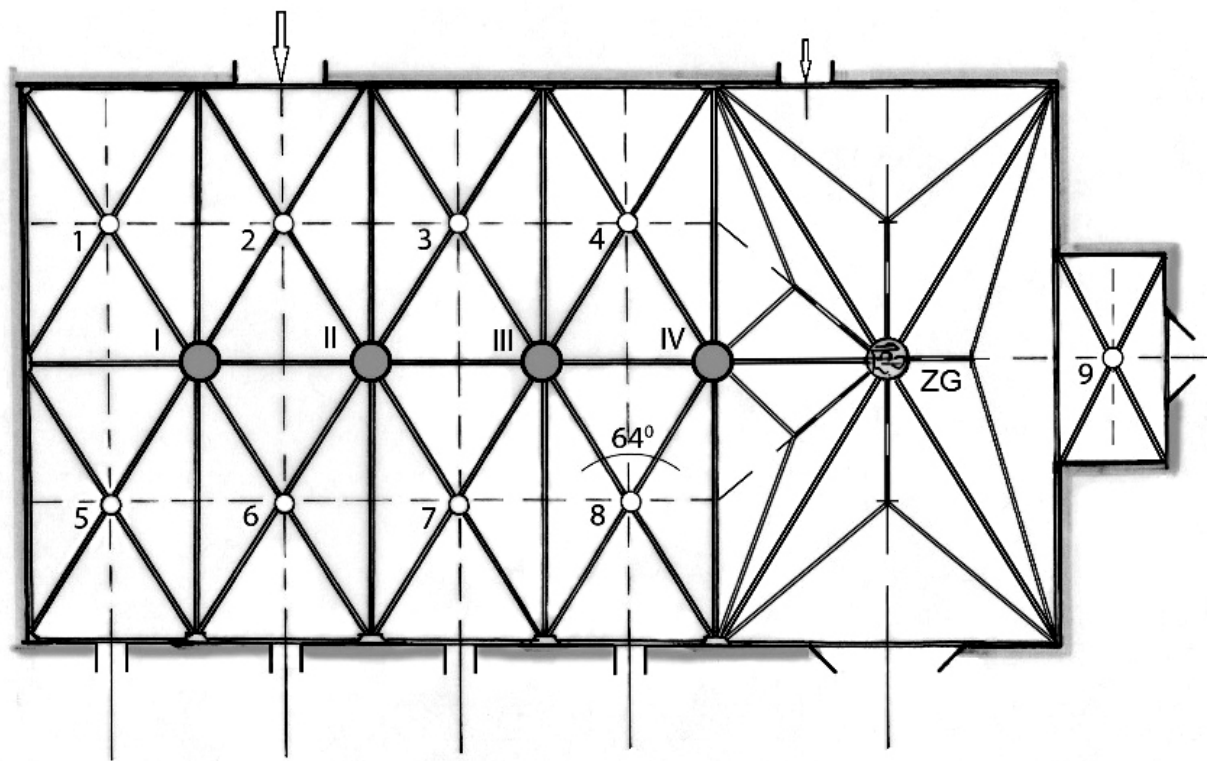

Il. 6 Schemat rzutu kościoła zamkowego w Toruniu wraz ze strukturą sklepień - próba rekonstrukcji, I-IV filary hali, 1-9 zworniki konstrukcyjne, ZG - zwornik główny. Kolor czarny - pierwsze sklepienie krzyżowo-żebrowe (liniami przerywanymi zaznaczono grzbiety wysklepek ostrołukowych), kolor czerwony - wariant z przęsłem gwiaździstym sklepienia chóru, oprac. K. Pospieszny

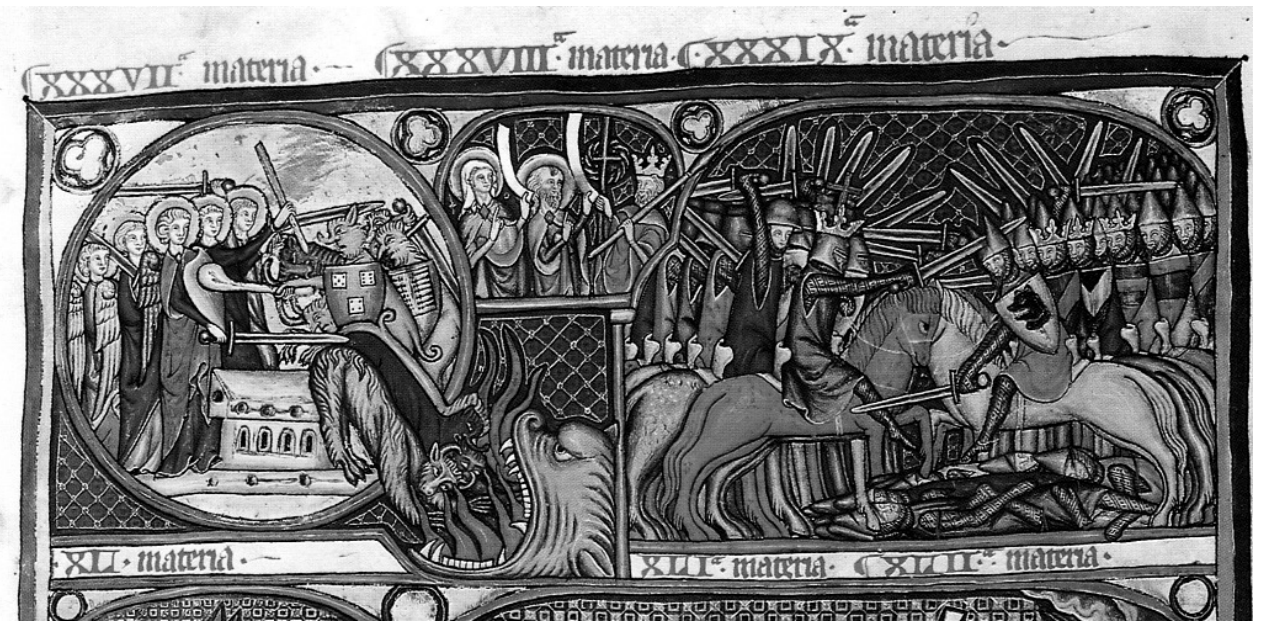

Il. 7 Walka archaniołów z szatanem i nowych Machabeuszy z ludami Goga i Magoga - iluminacja z krzyżackiej Apokalipsy Heinricha Heslera (fragment), egz. ze Stuttgartu, repr. za kat. 800 Jahre Deutscher Orden, Gütersloh 1990 


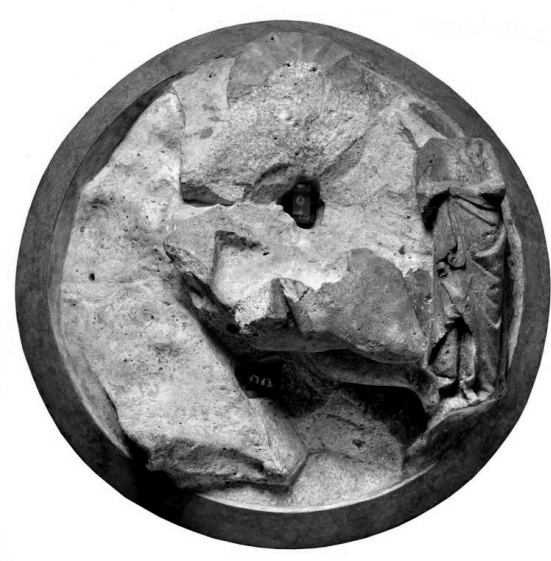

Il. 8a) Toruń, destrukt zwornika głównego z kościoła zamkowego, zbiory Muzeum Okręgowego w Toruniu, fot. A. Skowroński, fot. L. Okoński

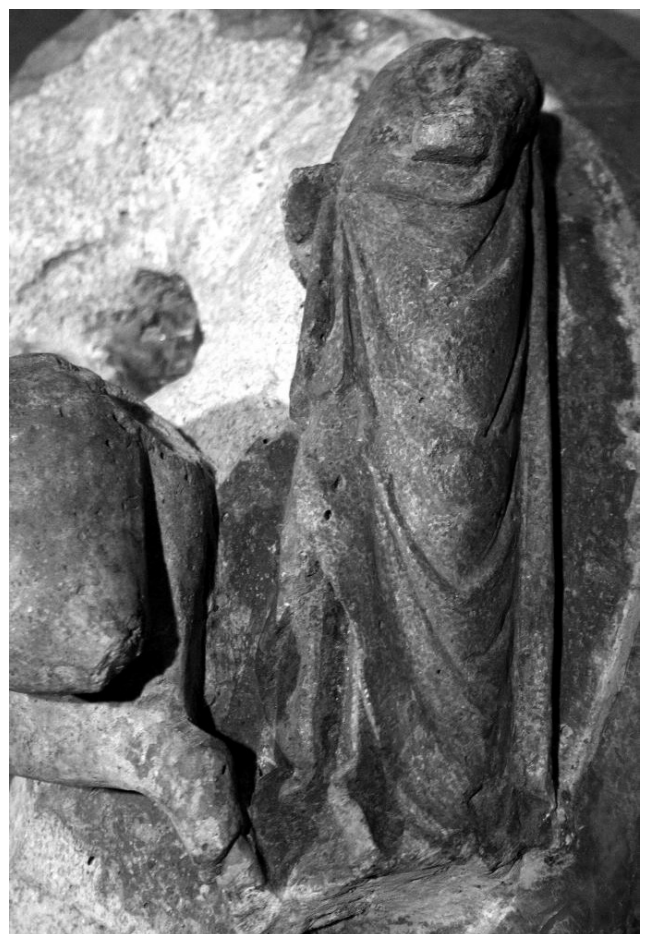

Il. 9a) postać stojąca, fragment zwornika głównego, Toruń, kościół zamkowy, fot. K. Pospieszny

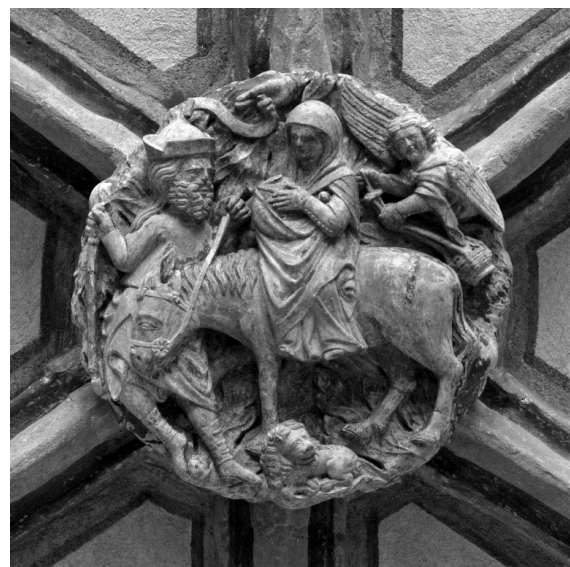

Il. 8b) Malbork - zwornik z Wielkiego Refektarza, fot. L. Okoński

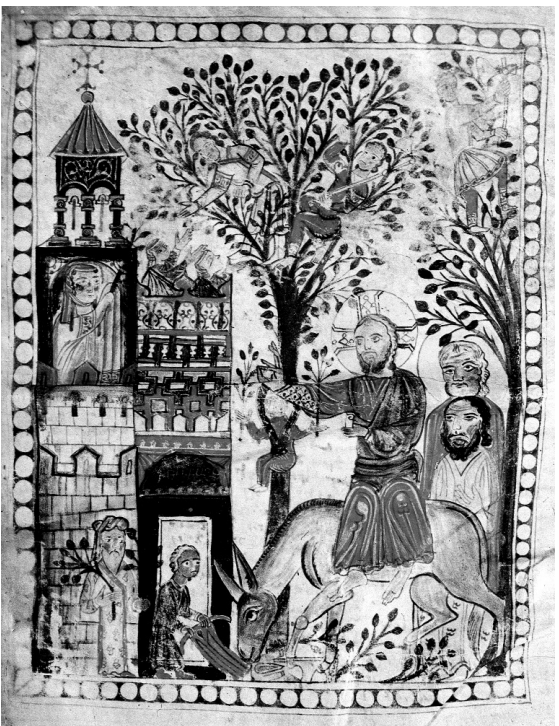

Il. 9b) miniatura Wjazd Chrystusa do Jerozolimy, Mistrz Markare, Klasztor Hachpat (Armenia), 1211 r., rep. za Sztuka Świata, t. III 


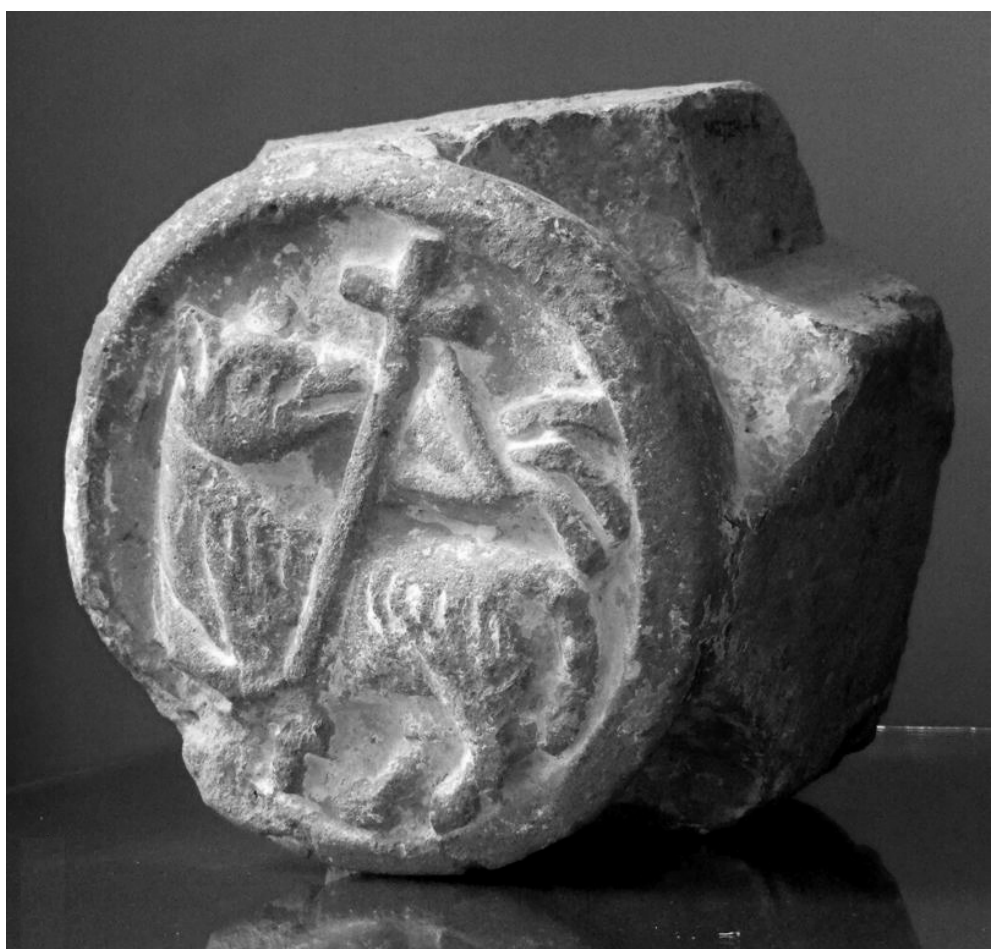

Il. 10 Toruń, zwornik z przedstawieniem Baranka Eucharystycznego z kościoła zamkowego, zbiory Muzeum Okręgowego w Toruniu, fot. K. Pospieszny 